\title{
Impact of Covid 19 on Different Sectors of the Economy
}

\author{
Dr. Y. Arundhathi* \\ Reader and HOD of Economic S.V.Arts College, Tirupati
}

\begin{abstract}
Millions of people affected with the outbreak of Corona virus. The entire world is affected with this virus and World Health Organization declared it as Pandemic. This virus has an unprecedented impact on the Global Economy. WHO declared public health emergency on 30th January 2020. Most of the countries are declared lockdown and affected normal life . As a result socio economic disruption, inhabiting the growth of entire economies. Almost all sectors of the economies affected with this pandemic and entire economic system needs emergency attention of the governments.
\end{abstract}

In India the first case of COVID19 reported in Kerala on January 30th 2020 and multiplied within two months. Government has declared lockdown on 24th march 2020. The estimated loss of corona virus is 26 billion US dollars in India by the end of June 2020. Lock down has restricted the economic and business activity of 1.3 billion people. In this paper an attempt is made to identify the impact of corona virus on different sectors of the Indian economy and highlight the reasons. So that it can be benefited in the post pandemic period for policy makers.

\section{INTRODUCTION}

Millions of people affected with the outbreak of Corona virus. The entire world is affected with this virus and World Health Organization declared it as Pandemic. This virus has an unprecedented impact on the Global Economy. WHO declared public health emergency on 30th January 2020. Most of the countries are declared lockdown and affected normal life. As a result socio economic disruption, inhabiting the growth of entire economies. Almost all sectors of the economies affected with this pandemic and entire economic system needs emergency attention of the governments.

In India the first case of COVID19 reported in Kerala on January 30th 2020 and multiplied within two months. Government of declared lockdown on 24th march 2020. the estimated loss of corona virus is 26 billion us dollars in India by the end of June 2020. Lock down has restricted the economic and business activity of 1.3 billion people. In this paper an attempt is made to identify the impact of corona virus on different sectors of the Indian economy. Therefore the objectives of the study are,

- To assess the general impact of corona virus on Indian economy.

- To assess sector wise impact of corona virus on Indian Economy during lock down period.
Estimated impact from COVID 19 on India's GDP 2020:

Quarterly estimation of GDP decline of over 9 percent between April and June 2020, a decrease of 5 percent growth in the beginning of 2020. India declared lockdown from march 25th to May 3rd which is restricting the economic activity from 1.3 billion people.

- Quarter on quarter growth

\begin{tabular}{|c|c|}
\hline April to June 2020 & -9.5 percent \\
\hline January to March 2020 & 5.2 percent \\
\hline October to November 2019 & 1.3 percent \\
\hline
\end{tabular}

Table 1

Estimated impact from covid 19 on India between April and June 2020 by sector GVA.

\begin{tabular}{|c|c|}
\hline & Growth rate \\
\hline $\begin{array}{c}\text { Mining and quarring and } \\
\text { MSMEs }\end{array}$ & $-14.2 \%$ \\
\hline $\begin{array}{c}\text { Financial real estate and } \\
\text { Professional services }\end{array}$ & $-16.9 \%$ \\
\hline $\begin{array}{c}\text { Gas Water electricity and } \\
\text { utility services }\end{array}$ & $-14 \%$ \\
\hline $\begin{array}{c}\text { Transport, hotels trade, } \\
\text { communication and } \\
\text { broadcasting services. }\end{array}$ & $-10 \%$ \\
\hline Overall GVA & $-9.8 \%$ \\
\hline $\begin{array}{c}\text { Agriculture, forestry , } \\
\text { fishing and manufacturing }\end{array}$ & $-1.4 \%$ \\
\hline $\begin{array}{c}\text { Defense public } \\
\text { administration and other } \\
\text { services. }\end{array}$ & $-0.4 \%$ \\
\hline
\end{tabular}

Table 2

\section{$>$ Mining and quarrying and MSMEs:}

Major problems in manufacturing industries are constraints in cash flow and supply chain disruptions. Mining industry is a worst hit of the pandemic and experienced a drastic drop in share prices. Demand decreases for metals and unemployment increases in mining workers. Mining and quarrying and MSMEs amount to -14.2 percent GVA. Global recession have a direct impact on exports. MSMEs contribute 40 percent of exports, the impact will be severe for a longer time. MSMEs are facing severe liquidity problems and the strain in banking system may expected to increase the credit gap in MSMEs. A slowdown in business activity in automotive construction and infrastructure will decrease the demand for basic metals. 
Financial real estate and professional services:

There is a major decline i.e. -16.9 percent in financial, real estate and professional services sector. Reserve Bank of India estimated that Non -Performing Assets may increase to 10 percent to 10.6 . percent by September 2020. This figure may increase with the outbreak of COVID 19. It is estimated that the pandemic will dampen real estate activity up to 2021. Due to non availability of credit brought down the sales of residential houses from 4.2 lakh units to 3 lakh units in COVID 19 period in top seven cities in India. Financial problems and global pandemic crisis led to unsettled investment climate and increases problems in professional services.

\section{Gas, water, electricity and utility services:}

There is sharp decline in GVA of (-14 percent) on Gas water, electricity and utility services. Lock down has drastically brought down the electricity consumption. Sources said that closure of offices, factories, stopping passenger services of Indian Railways resulted in slump.

Transport hotels, trade, communication and broad casting services:

We have noticed a sharp decline in transport, hotels trade communication and broad casting services by -10 percent. Though there is a lift on ban on travel ,both foreign tourists and domestic tourist movements are expected to remain very low because of increase in cases of COVID and highlighted risk. Social distancing and lack of disposable incomes restricted the travel. Slow down in transport and tourism sector will have knock on effects on hospitality and hotel industry. Communication and broadcasting industry is adversely affected. Revenues from advertisements will be dependent on revival of the aggregate demand in the economy.

\section{Agriculture, fishing , forestry:}

There is decline in GVA of agriculture, fishing, and forestry by - 1.4 percent. Due to lock down agriculture faced non availability of labor. Commercial crops and plantation crops are severely damaged as they tend to be more dependent on migrant labor. Crops like onion, cotton mango fisheries and vegetables are the worst hit of COVID19. Rise in labor costs lack of transport to market place increases losses to the farmers and hence allowing the crops to rot in the fields. Fisheries and entire supply chain activities affected due to 21 day lock down. This sector will contribute 1 percent of GDP and gives employment to 16 million people. Due to the lockdown small scale fishers has suffered economic blow.

\section{$>$ Defense Public Administration and other services:}

The GVA of defense public administration and other services accounted for -0.4 percent. To maintain balance between economic stability and geographical risk, we can expect that government will reduce the defense spending. Public spending increased on health and sanitation.

\section{CONCLUSIONS}

The end of lock down will not the end of problems. Structural transformation will bring forth latent opportunities within untapped real estate segments such as data centers, ware housing, integrated supply chains, establishing industrial parks, developing sezs, efficiency design maintaining social distancing and hygiene, creating hospitality spaces. Farmers are faced huge loses. Hence requesting governments to think of a rescheduling of loans where in existing loans are converted to long term loans. Government has given many relief packages fisheries sector has not received any package so far.

\section{REFERENCES}

[1]. Economic times. India times . com.

[2]. www.India today. in .

[3]. Dun and Bradstreet's Projections. 